Enferm Bras 2020;19(4Supl):S42-S49

https://doi.org/10.33233/eb.v19i4.4349

\title{
REVIEW \\ Rational pharmacological approach to clinical studies for the treatment of SARS-COV-2 infection
}

Antônia Dailane dos Santos Rabêlo*, Gizelle Gomes de Souza*, Rosilene Ribeiro de Sousa**, Charllyton Luis Sena da Costa, D.Sc. ${ }^{* *}$

*Undergraduate from Nursing Department, Centro Universitário Santo Agostinho, Teresina/PI, Brazil, **Especialista em Farmácia Clínica, Instituto Brasil de Pós-Graduação, Teresina/PI, Brazil, ${ }^{* * * D o u t o r ~ e m ~ B i o t e c n o l o g i a ~ p e l a ~ R E N O R B I O, ~ P h a r m a c y ~ D e p a r t m e n t, ~ C e n t r o ~ U n i v e r s i t a ́ r i o ~ S a n t o ~}$ Agostinho, Teresina/PI, Brazil

Received on: August 18; 2020; Accepted on: August 21; 2020.

Corresponding author: Charllyton Luis Sena da Costa, Rua Miguel Arcoverde, 191/203, Bloco C, Bairro Noivos, 64048-330 Teresina PI

Antônia Dailane dos Santos Rabêlo: daylanerabelo199519@gmail.com

Gizelle Gomes de Souza: gizellegomes1901@gmail.com

Rosilene Ribeiro de Sousa: rosersena@gmail.com

Charllyton Luis Sena da Costa : charllyton@gmail.com

\section{Abstract}

The global emergency generated by the COVID-19 pandemic caused by the SARS-COV-2 virus has created serious impacts on the different populations of the planet and has triggered the generation of scientific information on an unprecedented scale until then for a single topic. One of the consequences of the global scientific effort lies in the large number of substances already tested, by different methods, the search for an effective treatment for the infection and the consequent disease, remaining without absolute success so far. Assimilating the lessons, learned from the successful adoption of therapies combining multiple drugs used in HIV infection, the evidence obtained from the large amount of published information regarding the action of many substances with different mechanisms, now allows the proposition, in this work, of tests clinical trials for the evaluation of regimens composed of at least three drugs in combination. Rational combination schemes can target different molecular components of the virus affecting different points in the SARS-COV-2 replication cycle, such as virus fusion to the host cell, replication and viral particle assembly generating a potentially more effective synergistic effect than attempts using a single substance.

Keywords: antiviral, pandemic, combination therapy.

\section{Resumo}

\section{Abordagem farmacológica racional para estudos clínicos para o tratamento da infecção por SARS-COV-2}

A emergência mundial definida pela pandemia de COVID-19 causada pelo vírus SARS-COV-2 gerou graves impactos nas diferentes populações do planeta e desencadeou a geração de informações científicas sobre um único tema numa escala sem precedentes até então. Uma das consequências do esforço científico global reside no grande número de substâncias que já foram avaliadas, por diferentes métodos, a busca de um tratamento eficaz para a infecção da doença consequente, permanecendo sem sucesso absoluto até o momento. Assimilando os aprendizados da adoção, bem-sucedida, de terapêuticas combinando múltiplos fármacos utilizados na infecção pelo HIV, as evidências obtidas da grande quantidade de informação publicada relativas a ação de muitas substâncias com diferentes mecanismos, permite agora a proposição, neste trabalho, de testes clínicos para a avaliação de esquemas compostos por no mínimo três fármacos em combinação. Os esquemas racionais de combinação podem alvejar diferentes componentes moleculares do vírus afetando diferentes pontos do ciclo de replicação do SARS-COV-2, como a fusão do vírus à célula hospedeira, replicação e montagem da partícula viral gerando efeito sinérgico potencialmente mais eficaz do que as tentativas utilizando uma única substância por vez vista até então. 
Palavras-chave: antiviral, pandemia, terapia de combinação.

\section{Resumen \\ Enfoque farmacológico racional de los estudios clínicos para el tratamiento de la infección por SARS-COV-2}

La emergencia global generada por la pandemia COVID-19 provocada por el virus SARS-COV2 ha creado graves impactos en las diferentes poblaciones del planeta y ha desencadenado la generación de información científica a una escala sin precedentes hasta entonces para un solo tema. Una de las consecuencias del esfuerzo científico global radica en la gran cantidad de sustancias ya testadas, por diferentes métodos, la búsqueda de un tratamiento eficaz para la infección y la consecuente enfermedad, quedando sin éxito hasta el momento. La asimilación de las lecciones aprendidas de la exitosa adopción de terapias que combinan múltiples fármacos utilizados en la infección por $\mathrm{VIH}$, la evidencia obtenida de la gran cantidad de información publicada sobre la acción de muchas sustancias con diferentes mecanismos, permite ahora proponer, en este trabajo, pruebas. Ensayos clínicos para la evaluación de regímenes compuestos por al menos tres fármacos en combinación. Los esquemas de combinación racional pueden apuntar a diferentes componentes moleculares del virus que afectan diferentes puntos en el ciclo de replicación del SARS-COV-2, como la fusión del virus a la célula huésped, la replicación y el ensamblaje de partículas virales, generando un efecto sinérgico potencialmente más efectivo que los intentos de usar un solo sustancia.

Palabras-clave: antiviral, pandemia, terapia de combinación.

Introduction

The emergence and rise of the new coronavirus (SARS-COV-2), culminating in its spread on a pandemic scale, and generating unthinkable losses in human lives lost or severely affected by the disease resulting from the infection (COVID-19). This clearly generated a movement global in the scientific community towards understanding the new pathology as well as materialized in the search for effective forms of treatment [1]. This movement strengthened the efforts to fight the disease and generated a very large amount of information in a short period between the end of 2019 and July 2020. The number of citations to studies referenced in Pubmed until the end of July 2020 is 17,782 and by the end of 2019, there were only 10 .

The enormous volume of published studies clearly reflects the great effort and dedication of researchers around the world to produce knowledge that is capable of contributing to reducing the impacts of the pandemic on the different populations of the globe. One of the main aspects guiding the efforts dedicated to COVID-19 is directed to studies related to the development of new molecules endowed with absolute efficacy, until then not achieved, and the evaluation of molecular species already belonging to the therapeutic arsenal of humanity in search of the already mentioned efficacy [2-4]. The use of existing drugs in the context of treatment strategies adopted for aggravated cases followed a priori the paths of the clinical experience of professionals in the care of patients with COVID-19 and under the premise of using off label of pharmacological resources already available. Such an approach defined the demands for conducting clinical studies necessary to build a solid basis for the ostensibly safe use of treatment protocols and that have efficacy to compensate for the risks inevitably inherent in any pharmacological treatment $[5,6]$.

Many molecules have already been tested in different assessment situations and numerous are the promising individual cases that give rise to hopes for solving the central problem. Less common, however, are initiatives for rational assessment of treatment schemes based on the use of multiple drug therapy acting on different molecular systems of the target microorganism $[7,8]$. In this review, we propose the possibility of evaluating the efficacy and safety of pharmacological schemes combining different therapeutic agents in a synergistic way for the treatment of SARS-COV-2 infection in analogy to the combination antiretroviral therapy protocol used in HIV infection [9,10].

\section{Methods}

This work was performed as guided to the Preferred Reporting Items for Systematic Reviews and Meta-Analysis (PRISMA) statement. PubMed database was searched for studies concern pharmacological propositions related to COVID-19 through July 2020 without restrictions 
of time and language but limited to Clinical Trial filter. SARS-COV-2 and COVID-19 were the searching terms used.

The studies included in this work had to fulfill the following criteria: 1) Submit a clinical evaluation of one or more substances for the treatment of SARS-COV-2 infection. 2) Works not focused on the evaluation of palliative treatments, support or with natural products. One researcher extracted data and other one reviewed it from selected papers, to minimize discrepancies.

\section{Results and discussion}

The PRISMA flow diagram (Figure 1) presents records of reviewing process that result on 15 works after 54 originally returned on initial search.
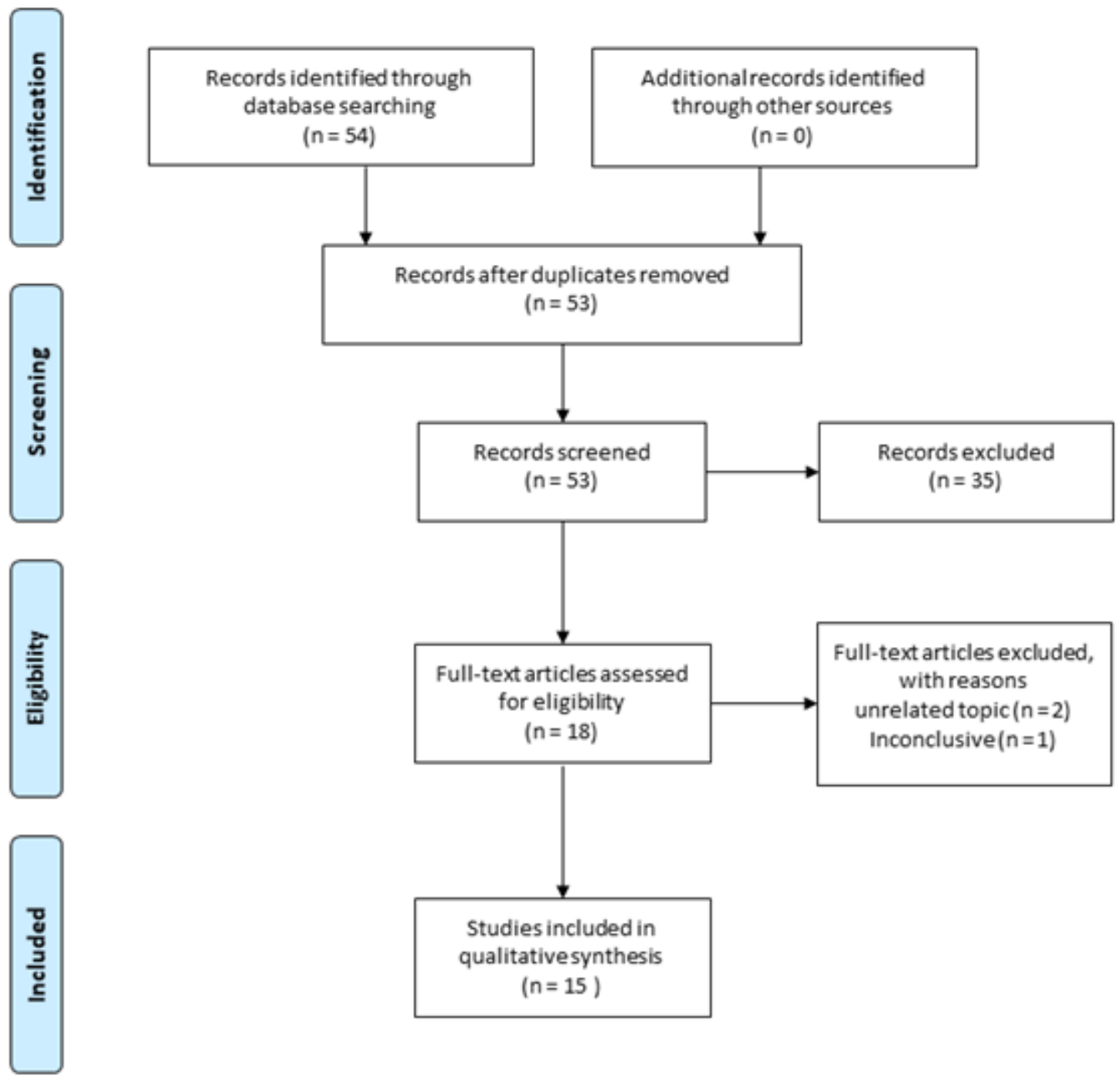

Figure 1 - PRISMA flow diagram for systematic selection of works.

Therapeutic approach to HIV infection

Many lessons offered, over the years, by the effort to develop specific drugs capable of contributing to the reduction of HIV viral load in patients. Among the legacies of this process, it is necessary to highlight the impact generated by the introduction of HIV protease inhibitors on the success of treatment [11-13], but also by highlighting the evident superiority of therapeutic schemes based on multiple drugs compared to strategies centered on use of a single drug or pharmacological category. The drug approach aimed at multiple molecular targets in HIV [14-16], 
thus allows a synergistic effect and reduces the scope of adaptive adjustments of viral metabolism to attacks produced by a single drug on a single target.

The drugs allocated in Table I, which are part of the main therapeutic regimens used in HIV combined antiretroviral therapy in current clinical practice. The therapeutic regimes presented here are organized as present in the WHO Guidelines [17] updated in December 2018 and adapted for this work. The different drug regimens are in order of preference for the initiation of treatment, as well as the relation of indication of each regimen by population groups considering gender, age group and reproductive capacity.

Table I - Summary of the reference therapeutic regimes, proposed by the WHO, applicable to the treatment of patients with HIV infection.

\begin{tabular}{|c|c|c|c|}
\hline Populations & Prefirred regimen & alternative regimen & Special situations \\
\hline \multirow{5}{*}{$\begin{array}{l}\text { Adult men and } \\
\text { adolescent boys }\end{array}$} & $\mathrm{TDF}+3 \mathrm{TC}+\mathrm{DTG}$ & $T D F+3 T C+E^{3}$ & $A Z T+3 T C+E F V^{3}$ \\
\hline & & & \\
\hline & $\mathrm{TDF}+\mathrm{FTC}+\mathrm{DTG}$ & $\mathrm{TDF}+\mathrm{FTC}+\mathrm{EFV}^{\circ}$ & $\mathrm{TDF}+3 \mathrm{TC}+\mathrm{Pl} / \mathrm{r}$ \\
\hline & & & \\
\hline & & & $\mathrm{TDF}+\mathrm{FTC}+\mathrm{Pl} / \mathrm{r}$ \\
\hline \multirow{5}{*}{$\begin{array}{l}\text { Adult women } \\
\text { and adolescent } \\
\text { girls }\end{array}$} & TDF + 3TCor & $T D F+3 T C+E F V^{b}$ & $\mathrm{AZT}+3 \mathrm{TC}+\mathrm{EFV}^{a}$ \\
\hline & & & \\
\hline & $\mathrm{TDF}+\mathrm{FTC}+\mathrm{EFV}^{\mathrm{a}}$ & $\mathrm{TDF}+\mathrm{FTC}+\mathrm{EFV}^{\circ}$ & $\mathrm{TDF}+3 \mathrm{TC}+\mathrm{RAL}$ \\
\hline & & $T D F+3 T C+A T V / r$ & $\begin{array}{l}\text { or } \\
\text { TDF + FTC + RAL }\end{array}$ \\
\hline & & $\begin{array}{l}\text { or } \\
\text { TDF + FTC + ATV/r }\end{array}$ & \\
\hline \multirow[t]{6}{*}{ Children } & $\mathrm{ABC}+3 \mathrm{TC}+\mathrm{DIG}$ & $\mathrm{ABC}+3 \mathrm{TC}+\mathrm{LPV}$ & $\mathrm{ABC}+3 \mathrm{TC}+\mathrm{EFV}$ \\
\hline & & $A B C+3 T C+R A L$ & $\begin{array}{l}\text { or } \\
\mathrm{ABC}+3 \mathrm{TC}+\mathrm{NVP}\end{array}$ \\
\hline & & & $A Z T+3 T C+E F V$ \\
\hline & & & $\begin{array}{l}\text { or } \\
A Z T+3 T C+N V P\end{array}$ \\
\hline & & & $\mathrm{AZT}+3 \mathrm{TC}+\mathrm{LPV} / \mathrm{r}$ \\
\hline & & & $\begin{array}{l}\text { or } \\
A Z T+3 T C+R A L\end{array}$ \\
\hline Newborn & $A Z T+3 T C+R A L$ & $\mathrm{AZT}+3 \mathrm{TC}+\mathrm{NVP}$ & $\mathrm{AZT}+3 \mathrm{~T} C+\mathrm{LPV} / \mathrm{r}$ \\
\hline
\end{tabular}

Abacavir (ABC), Emtricitabine (FTC), Lamivudine (3TC), Zidovudine (AZT), enofovir disoproxil fumarate (TDF), Efavirenz (EFV), Nevirapine (NVP), Atazanavir/ritonavir (ATV/r), Lopinavir/ritonavir (LPV/r), Dolutegravir (DTG), Raltegravir (RAL). $\mathrm{a}=600 \mathrm{mg} ; \mathrm{b}=400 \mathrm{mg}$

In a quick analysis of the information summarized in Table I on the therapeutic classes that contribute to the composition of the different anti-HIV therapeutic regimens, it is possible to observe representatives of the following classes: Nucleoside Inhibitors of Reverse Transcriptase, Nucleotide Inhibitors of Reverse Transcriptase, Non-Nucleoside Inhibitors of Reverse transcriptase, Protease Inhibitors and Integrase Inhibitors. In this way, there are five different classes of molecules with pharmacological activities centered on the action on three different molecular targets critical to the HIV infection cycle.

The undisputed success of antiretroviral therapy in reducing viral load, to almost undetectable levels, in HIV-infected patients is, of course, also a consequence of the combined use of different molecules acting in synergy to reduce viral replication [18,19]. Evidence of the value of the combination therapy can be seen in the composition of the 28 therapeutic regimens present in Table I. The enzyme Reverse Transcriptase is clearly the preferred molecular target for all the therapeutic regimens listed, since Reverse Transcriptase Inhibitors contribute two of the three drugs in all triple regimens and are half of those with four drugs. Still, none of the therapeutic approaches listed in Table I fails to use drugs targeting other molecular components of the virus in the successful intention of extending their antiviral efficacy.

The use of drugs in the class of HIV Protease Inhibitors and Integrase inhibitors, as well as the use of more than 1 Reverse Transcriptase Inhibitor per therapeutic regimen reinforce the argument. A therapeutic strategy centered on action on multiple targets using different drugs is a logical path for proposing clinical studies aimed at evaluating treatment strategies for viral infections causing illnesses that had not been treated [20]. 
Candidates for clinical studies to define a combined pharmacological approach for SARS-COV2.

Despite the evidence of success presented by the strategy of combining drugs with multiple mechanisms of action for the treatment of HIV infection, only 1 of the 54 works classified in the PubMed as clinical trial (1,85\%), until July 2020 ends, presented more than two drugs as a treatment alternative for SARS-COV-2 infection, one of which is interferon beta-1b [21-25]. While chloroquine or hydroxychloroquine were evaluated in 7 of 54 studies in the same category (12.96\%).

The only study using a triple drug regimen, containing interferon beta-1b, Lopinavirritonavir and ribavirin, found statistically significant results in reducing symptoms and positive findings from tests with nasopharyngeal swabs. Another point to highlight is the absence of significant findings when considering the adverse events of the group undergoing treatment with the triple regimen in comparison with the control group, allowing to ponder that the increase in therapeutic agents did not result in automatic elevation of risks in the study. This result, although solitary among clinical studies, testifies in favor of the argument of the superiority of multidrug regimens, and the need for more clinical tests for drug combination regimens, for the treatment of viral infections, since in that study the group the control used only the protease inhibitor Lopinavir-ritonavir [21], which is part of treatment protocols against HIV. This characteristic is further reinforced by the inability to produce statistically significant results in clinical studies that independently used the drugs Lopinavir-ritonavir [22], Remdesivir [22,23], Ruxolitinib [24] and Oseltamivir [25], although the findings in all these studies indicated improvements in the clinical conditions of patients undergoing different treatments with each drug.

Because of the focus of the global scientific community on attempts to understand and resolve the disease caused by SARS-COV-2, many drugs have been tested against the microorganism and different mechanisms of action and molecular targets have been determined [26-28]. In Table II, some drugs are grouped by strategy of action on the virus and can be used in the definition of multiple schemes for clinical testing aiming at the evaluation of efficacy and safety and then their possible uses in treatment strategies aiming at the reduction of viral load and consequently of typical COVID-19 characters.

Table II - Candidate drugs for conducting clinical studies to build multiple antiviral regimens for treating SARS-VOC-2 infection grouped by strategy of action on viral infection cycle.

\begin{tabular}{|c|c|c|}
\hline Cell entry action & Action on replication & Assembly action \\
\hline Chloroquine ${ }^{29}$ & Remdesivir ${ }^{2,29}$ & Lopinavir/ritonavir ${ }^{2,29}$ \\
\hline Camostat Mesilate 2,29 & Ribavirin 21,31 & Dolutegravir ${ }^{20,} 34$ \\
\hline $\begin{array}{l}\text { Nafamostat Mesilate } 29,31 \\
\text { Baricitini } 2,8,30\end{array}$ & Favipiravir $^{2,29}$ & Saquinavir 8,34 \\
\hline Umifenovir $^{29}, 31,32$ & & Efavirenz ${ }^{8,}, 34$ \\
\hline
\end{tabular}

Table II brings together drugs that have different specific molecular targets and can affect three critical steps for the viral replication: cycle, Cell entry, replication of the virus genetic material and assembly of the viral particles. The activity assignments of the molecules listed in the table are widely documented $[2,8,21,29-32,34]$, and represent a strategy predominantly based on targeting viruses, in which the molecular targets of the drugs listed belong primarily to the virus and not to the host, as well as the commercial availability of the drugs presented.

Considering the drugs listed in Table II that act by interfering with the entry of the virus into cells, there are three different molecular mechanisms to be explored in proposals for combined antiviral treatment schemes for SARS-COV-2. In the column of drugs that act to affect the replication capacity of the virus RNA, there are drugs that can affect the action of RNAdependent RNA polymerase (RdRp) and that can compose a possible therapeutic scheme combined one at a time or with more than one representative. The column, in table 2, containing drugs capable of interfering with the assembly of the viral particles. In this category are the representatives with the fewest direct evidence of application on SARS-COV-2 so far, however, preliminary studies have pointed out the possibility that the listed molecules inhibit the main protease of the virus, which is responsible for post-synthesis processing of polypeptides translated from viral RNA $[2,8,29]$.

A rational, and potentially effective, pharmacological treatment strategy focused on reducing the number of viral particles in infected individuals could use at least one representative from each group shown in Table II. The proposal for clinical tests to evaluate efficacy and safety 
of various combinations of drugs capable of acting in different biochemical systems, linked to the viral life cycle, can generate a synergistic effect in order to increase their chances of success in the treatment of infected patients. The definitions of combined therapeutic schemes to be tested should not be restricted to the examples of drugs presented in Table II but should consider the presence of molecules capable of simultaneously affecting the functioning of multiple molecular mechanisms critical for viral replication previously known.

Conclusion

The intense work of many researchers around the world has generated strong evidence related to the action of many drugs on different molecular targets associated with the SARS-COV2 infection cycle. Thus, we propose the clinical evaluation of combined antiviral regimens containing at least three drugs as a rational alternative to be considered, as opposed to singledrug regimens for the treatment of SARS-COV-2 infection, which had not yet been effective.

References

1. World Health Organization. COVID-19 Global Research Roadmap: 2019 Novel coronavirus. Geneva, Switzerland: WHO; 2020.

2. Li H, Zhou Y, Zhang M, Wang H, Zhao Q, Liu J. Updated approaches against SARSCoV-2. Antimicrob Agents Chemother 2020;64(6):e00483-20.

https://doi.org/doi.org/10.1128/AAC.00483-20

3. Hussain S, Xie YJ, Li D, Malik SI, Hou JC, Leung EL et al. Current strategies against COVID-19. Chinese Medicine 2020;15(70). https://doi.org/10.1186/s13020-020-00353-7

4. Li G, De Clercq E. Therapeutic options for the 2019 novel coronavirus (2019-nCoV). Nat Rev Drug Discov 2020;19(3):149-50. https://doi.org/10.1038/d41573-020-00016-0

5. Cao B, Wang Y, Wen D, Liu W, Wang J, Fan G et al. A trial of lopinavir-ritonavir in adults hospitalized with severe covid-19. New Engl J Med 2020;382(19):1787-99. https://doi.org/10.1056/NEJMoa2001282

6. Molina JM, Delaugerre C, Le Goff J, Mela-Lima B, Ponscarme D, Goldwirt L et al. No evidence of rapid antiviral clearance or clinical benefit with the combination of hydroxychloroquine and azithromycin in patients with severe COVID-19 infection. Med Mal Infect 2020;50(4):384. https://doi.org/10.1016/j.medmal.2020.03.006

7. Caly L, Druce JD, Catton MG, Jans DA, Wagstaff KM. The FDA-approved drug ivermectin inhibits the replication of SARS-CoV-2 in vitro. Antiviral Res 2020;178:104787. https://doi.org/10.1016/i.antiviral.2020.104787

8. Lotfi M, Hamblin MR, Rezaei N. COVID-19: Transmission, prevention, and potential therapeutic opportunities. Clin Chim Acta 2020;508:254-66.

https://doi.org/10.1016/..cca.2020.05.044

9. Maenza J, Flexner C. Combination antiretroviral therapy for HIV infection [published correction appears in Am Fam Physician 1998;58(5):1084. Am Fam Physician 1998;57(11):2789-98.

10. Eggleton JS, Nagalli S. Highly Active Antiretroviral Therapy (HAART) [Updated 2020 Jul 5]. Treasure Island FL: StatPearls; 2020.

11. Wensing AM, van Maarseveen NM, Nijhuis M. Fifteen years of HIV Protease Inhibitors: raising the barrier to resistance. Antiviral Res 2010;85(1):59-74. https://doi.org/10.1016/j.antiviral.2009.10.003

12. Broder S. The development of antiretroviral therapy and its impact on the HIV-1/AIDS pandemic. Antiviral Res 2010;85(1):1-18. https://doi.org/10.1016/j.antiviral.2009.10.002

13. Lv Z, Chu Y, Wang Y. HIV protease inhibitors: a review of molecular selectivity and toxicity. HIV AIDS (Auckl) 2015;7:95-104. https://doi.org/10.2147/HIV.S79956

14. Powderly WG. Integrase inhibitors in the treatment of HIV-1 infection. J Antimicrob Chemother 2010;65(12):2485-8. https://doi.org/10.1093/jac/dkq350

15. Penazzato M, Giaquinto $C$. Role of non-nucleoside reverse transcriptase inhibitors in treating HIV-infected children. Drugs 2011;71(16):2131-49. https://doi.org/10.2165/11597680-000000000-00000

16. Moran CA, Weitzmann MN, Ofotokun I. The protease inhibitors and HIV-associated bone loss. Curr Opin HIV AIDS 2016;11(3):333-42.

https://doi.org/10.1097/COH.0000000000000260 
17. World Health Organization. Updated recommendations on first-line and second-line antiretroviral regimens and post-exposure prophylaxis and recommendations on early infant diagnosis of HIV: supplement to the 2016 consolidated guidelines on the use of antiretroviral drugs for treating and preventing HIV infection - December 2018. Geneva: WHO; 2018.

18. Maeda K, Das D, Kobayakawa T, Tamamura H, Takeuchi H. Discovery and Development of anti-HIV therapeutic agents: progress towards improved HIV medication. Curr Top Med Chem 2019;19(18):1621-49. https://doi.org/10.2174/1568026619666190712204603

19. Chaudhuri S, Symons JA, Deval J. Innovation and trends in the development and approval of antiviral medicines: 1987-2017 and beyond. Antiviral Res 2018;155:76-88. https://doi.org/10.1016/i.antiviral.2018.05.005

20. Himmel DM, Arnold E. Non-nucleoside reverse transcriptase inhibitors join forces with integrase inhibitors to combat HIV. Pharmaceuticals (Basel) 2020;13(6):122. https://doi.org/10.3390/ph13060122

21. Hung IF, Lung KC, Tso EY, Liu R, Chung TW, Chu MY et al. Triple combination of interferon beta-1b, lopinavir-ritonavir, and ribavirin in the treatment of patients admitted to hospital with COVID-19: an open-label, randomised, phase 2 trial. Lancet 2020;395(10238):1695-1704. https://doi.org/10.1016/S0140-6736(20)31042-4

22. Wang Y, Zhang D, Du G, Du R, Zhao J, Jin Y et al. Remdesivir in adults with severe COVID-19: a randomised, double-blind, placebo-controlled, multicentre trial. Lancet 2020;395(10236):1569-78. https://doi.org/10.1016/S0140-6736(20)31022-9

23. Antinori S, Cossu MV, Ridolfo AL, Rech R, Bonazzetti C, Pagani G et al. Compassionate remdesivir treatment of severe Covid-19 pneumonia in intensive care unit (ICU) and Non-ICU patients: Clinical outcome and differences in post-treatment hospitalisation status. Pharmacol Res 2020;158:104899. https://doi.org/10.1016/j.phrs.2020.104899

24. Cao Y, Wei J, Zou L, Jiang T, Wang G, Chen $L$ et al. Ruxolitinib in treatment of severe coronavirus disease 2019 (COVID-19): A multicenter, single-blind, randomized controlled trial. J Allergy Clin Immunol 2020;146(1):137-46.e3. https://doi.org/10.1016/i.jaci.2020.05.019

25. Coenen S, van der Velden AW, Cianci D, Goossens H, Bongard E, Saville BR et al. (2020). Oseltamivir for coronavirus illness: post-hoc exploratory analysis of an openlabel, pragmatic, randomised controlled trial in European primary care from 2016 to 2018. BR J Gen Pract 2020;70(696):e444-e9. https://doi.org/10.3399/bjgp20X711941

26. Lu CC, Chen MY, Lee WS, Chang YL. Potential therapeutic agents against COVID-19: What we know so far. J Chin Med Assoc 2020;83(6):534-6. https://doi.org/10.1097/JCMA.0000000000000318

27. Park SJ, Yu KM, Kim YI, Kim SM, Kim EH, Kim SG et al. Antiviral efficacies of FDAapproved drugs against SARS-CoV-2 Infection in Ferrets. mBio, 2020;11(3):e01114-20. https://doi.org/10.1128/mBio.01114-20

28. Yamaya M, Nishimura H, Deng X, Kikuchi A, Nagatomi R. Protease inhibitors: candidate drugs to inhibit severe acute respiratory syndrome coronavirus 2 replication. Tohoku J Exp Med 2020;251(1):27-30. https://doi.org/10.1620/tjem.251.27

29. McKee DL, Sternberg A, Stange U, Laufer S, Naujokat C. Candidate drugs against SARS-CoV-2 and COVID-19. Pharmacol Res 2020;157:104859. https://doi.org/10.1016/j.phrs.2020.104859

30. Richardson P, Griffin I, Tucker C, Smith D, Oechsle O, Phelan A et al. Baricitinib as potential treatment for 2019-nCoV acute respiratory disease. Lancet 2020;395(10223):e30-e31.https://doi.org/10.1016/S0140-6736(20)30304-4

31. Zhou H, Fang Y, Xu T, Ni WJ, Shen AZ, Meng XM. Potential therapeutic targets and promising drugs for combating SARS-CoV-2. Br J Pharmacol 2020;177(14):3147-61. https://doi.org/10.1111/bph.15092

32. Boriskin YS, Pécheur El, Polyak SJ. Arbidol: a broad-spectrum antiviral that inhibits acute and chronic HCV infection. Virol J 2006;3:56. https://doi.org/10.1186/1743-422X3-56

33. Huang $D, Y u H$, Wang $T$, Yang $H$, Yao R, Liang Z. Efficacy and safety of umifenovir for coronavirus disease 2019 (COVID-19): A systematic review and meta-analysis ahead of print 2020 Jul 3. J Med Virol 2020;10. https://doi.org/10.1002/imv.26256 
34. Beck BR, Shin B, Choi Y, Park S, Kang K. Predicting commercially available antiviral drugs that may act on the novel coronavirus (SARS-CoV-2) through a drug-target interaction deep learning model. Comput Struct Biotechnol J 2020;18:784-90.

https://doi.org/10.1016/j.csbj.2020.03.025 